\title{
Determinants of Mompreneur Performance in the Pandemic Era (Case Study of Medan City Mompreneurs)
}

\author{
Aisyah $^{1}$, Arif Qaedi Hutagalung ${ }^{2}$, Fivi Rahmatus Sofiyah ${ }^{3}$ \\ ${ }^{1,2,3}$ Department of Management, University of Sumatera Utara, Medan, Indonesia. \\ Corresponding Author: Aisyah
}

\begin{abstract}
The existence of the Covid-19 pandemic that attacks all parts of the world causes various problems ranging from physical, psychological, spiritual and economic health. Government of Indonesia in order to reduce the number of growth positive Covid-19 then make various kinds of policies. Meanwhile, women due to the Covid-19 pandemic bear a double burden, because of the work from home and school from home policies. Thus, women must be able to allocate their time to take care of the household, accompany their children to study, as well as work. The purpose of women entering the business world is not only about financial problems, but also to follow the intrinsic needs and a sense of satisfaction with the achievements that have been made, especially mompreneurs in Indonesia can be a driving force in the process of empowering women which has a positive impact on the country's economy, especially in helping the family economy. Mompreneur generally start business from small to capitalize skills and capital are limited. Mompreneur is believed to continue to grow from the small business level to become a large business and even be able to compete at the international level. The purpose of the study is to analyze the influence of self-efficacy, selfesteem, the orientation of the market and the orientation of the innovation to the performance of mompreneur through a commitment to entrepreneurship. This research was conducted in the city of Medan on mompreneur with a sample of 255 respondents. Results of the study showed that self-efficacy, self-esteem, the orientation of the market and the orientation of the innovation impact significantly on the
\end{abstract}

performance of mompreneur through a commitment to entrepreneurship.

Keywords: Self Esteem, Self Efficacy, Market Orientation, Market Innovation, Performance of Mompreneur, Commitment to Entrepreneurship

\section{INTRODUCTION}

Indonesia struck by the case of the so-called pandemic Covid-19, which is triggered by the corona virus (Covid-19) at the beginning of the year 2020. The virus's entry into Indonesia and began attacking several people who never did a trip out of the country, especially the country of China. The case of the day -by- day continues to experience an increase. Viruses were born from the city of Wuhan have been infecting thousands and even millions of the population of humans from various parts of the world. The World Health Organization (WHO) has decided that the Corona virus is considered a pandemic that can make people from all walks of life experience anxiety.

The existence of the Covid-19 pandemic that attacks all parts of the world causes various problems ranging from physical, psychological, spiritual and economic health. Government of Indonesia in order to reduce the number of growth positive Covid-19 then make various kinds of policies. Starting from Lockdown partially, PSBB, work from home (WFH), stay at home, isolation, social distancing and even quarantine area. Where entire communities are encouraged to not carry out 
activities in outside the home, including work (Nurkidam et al., 2020).

While the women as a result of the pandemic covid-19 bear the burden of double, because of their policy work from home (WFH / work from home) and also school from home (SFH/school from home). Thus, women must be able to allocate their time to take care of the household, accompany their children to study, as well as work. The condition is a result of the unequal division of tasks.

Number of entrepreneurs women in Indonesia is still relatively very low $0.1 \%$ of the total population. Employers women or often referred to with the term womenpreneur that success began to pursue a career on the bottom with the nature of the innovative, painstaking, abstinence surrender and committed to undergo the entrepreneurial process (Hendratni \& Ermalina, 2018). The purpose of women entering the business world is not only about financial matters, but to follow the intrinsic needs and a sense of satisfaction with the achievements that have been made. However, still there is a gap of gender that men are considered more have the knowledge and skills that is enough to run a business. Different opinion with Tyahya who explained that womenpreneurs, especially mompreneurs in Indonesia, can be a driving force in the process of empowering women who have a positive impact on the country's economy, especially in helping the family economy (Hendratni \& Ermalina, 2018).

Habituation works like this would bring the impact that positive, for example if experiencing the trials of women can be independent and strong. Now women after getting married not only can play a role as the mother house stairs alone but have equality of gender to do business from home in order to support the needs of his life. Mother house stairs have opportunities that equal to succeed in the world of business to be mompreneur. Being a mompreneur has many advantages one of them while working the flexibility that can be tailored to the family. Mom was still able to do the work home household who tandem with running the business (Rachmawati, 2011).

Mompreneur generally start business from small to capitalize skills and capital are limited. Mompreneur is believed to continue to grow from the small business level to become a large business and even be able to compete at the international level (Koorsgaard, 2007). In some countries developed the mompreneur come together and form a community to gather strength and mutual give encouragement (Duberley and Carrigan 2015). Community mompreneur it has meaning important to the mompreneur, particularly the exchange of information and technology. Their communities make the mompreneur able to expand the area of marketing and networking.

Rival and Sagala (2009) stated that the performance is a thing that is very important in the efforts of the company to achieve its objectives. In theory, there are a variety of ways to improve performance, such as self esteem and self efficacy. In the relation between self-esteem and self efficacy with the performance mompreneur, there are a number of studies are mutually contradictory. Sapariyah's research (2011) shows that self-esteem and self-efficacy have a positive and significant effect on employee performance. However, different results were found by other researchers. Indrawati (2014) find that self-esteem does not affect it significantly to the performance of the employee. Similarly, Kaseger (2013) found that self-efficacy has no significant effect on performance. With the inconsistencies are certainly interesting to do research much more about the influence of self esteem and self efficacy against performance.

Orientation innovation are characteristics and values are embraced by the entrepreneur's own that is the nature of abstinence surrender, dare to take risks, speed and flexibility (Debbie Liao and Philip Sohmen, 2001). Orientation innovation emphasizes the passion for 
creating innovative businesses, as a refresher of congestion businesses, which often accompany the pace early innovation (Zhou, et al., 2005). According to Naver and Slater (1990) The orientation of the market is the culture of the business $y$ ang able to create behaviors that support the efforts of the creation of value provided to the customer. Meanwhile, Jaworski \& Kohli (1993), stated that market orientation has the potential to improve performance. Besides that, the orientation of the market is believed to also provide the benefit psychologically and socially, in the form of a feeling of pride and sense of belonging that is great, as well as the commitment of organizational which is great as well. Application of orientation market will bring an increase performance (Tjiptono et al, 2008).

\section{LITERATURE REVIEW Mompreneur}

Mompreneur is a combination of the two tribes said that mommy or mom and an entrepreneur or entrepreneurs. According Malahayati (2015), the term of mompreneur given to the mother households who own and manage the business itself. Ability mompreneur in the balance between activity as mothers and entrepreneurs are considered able to be a challenge for the development of the ideology of entrepreneurs who believe that the purpose of self-employment is obtaining profits (Koorsgard,2007). Mompreneur is the generation of new of women entrepreneurs are growing due to the encouragement needs to balance life settle down stairs with the need for work/perform activities of productive (Sutikno and Novita, 2009). Although considered as part of the new generation, the phenomenon of mompreneur is not a new phenomenon. According to Huet et al. (2013), mompreneur just a concept look that is new to the group of entrepreneurs who still need a definition of theoretical are supported empirically valid. Costin (2012) find that motivation mompreneur to start a business the flexibility that is high and the freedom to manage business by considering the commitment of the family. Motivation that comes from the family is considered to be a source of conflict if the mompreneur decides to expand his business. So it becomes a challenge for the mompreneur in later today to ascertain the reasons start a business. The presence of technology for mompreneurs is important but creates a high dependence between mompreneurs and the development of technology, information and communication (ICT). Almost all activities, both transactions and innovations, depend on the development of ICT so that ICT becomes the backbone of business.

\section{Self Esteem}

According to Demirdag (2015) the price of self (self-esteem) is the assessment of individuals to honor themselves, through attitude towards her own which is its implicit and not illustrates the extent to which people are judging him as a person who have capabilities, significance, value and competent and according Gunaputri et al (2016) the price of self (self-esteem) is the rate at which a person believes that he is an individual that is valuable and worthy. People with the price of self- height more likely to look for a job with the status of more height, more trust themselves in their ability There are six factors that can support to build self-esteem are usually shortened by GROWTH (Sapariyah, 2011), namely: goal setting (plan objectives); risk taking (taking risks); opening up (opening up); wisechoice making (making decisions are wise); time sharing (runs according to time); and healing (healing).

\section{Self Efficacy}

According to Ormrod (2009) selfefficacy is a person's assessment of his own ability to carry out certain behaviors or achieve certain goals. Efficacy themselves not be confused with the assessment of the consequences that would result from a behavior, but it will help determine the results of which are expected (Hidayat, 2011: 156). Bandura (in Chowdhury, 2009) 
states that the efficacy of self is the belief someone on the ability of him to do something work and earn achievements particular. More advanced Bandura stated that the efficacy of self- will determine how a person to think, act and motivate themselves they are facing difficulties and problems. A person's success or failure when performing a particular task is determined by his or her efficacy. People who have the efficacy of self that high would be able to face failure and obstacles that they face, stable emotions, behave and have the locus of control are high.

Efficacy of self is trust someone on the ability of him to finish a job. Conditions motivation someone who is more based on what that they believe rather than what that is objectively true. According Alwisol (2010) efficacy is the assessment themselves, whether to perform the action that good or bad, right or wrong, can or not be able to work in accordance with the requirement. Alwisol also suggests that the way people behave in situations specified depending on the relationship between the environment with the condition of the cognitive, especially the factor of cognitive are associated with the belief that he is able or not able to bring the behavior that is in accordance with expectations, the belief is known by the term efficacy of self.

\section{Innovation Orientation}

Innovation orientation plays an important role in improving business performance. Miller and Friesen (1982) in the journal Andwiani Sinarsari (2013) state that innovation orientation into a meaning that can be acceptable to explain the performance. Porter (2008) defines the orientation of innovation as a strategy benefits the company to be able to compete in more effectively in the market place are the same. Orientation innovation refers to the processes, practices, and decisionmaking that push to the direction of input of new and has three aspects of innovation, which is always innovative, act in a proactive and dare to take risks (Lumpkin and Dess, 1996). The innovation orientation which is reflected in the attitude full of innovation, being proactive and the courage to take risks is believed to be able to boost the company's performance. This is confirmed by Covin and Slevin (1991); Wiklund (1999), which states that the orientation of the innovation that is getting high can increase the ability of the company to market its products to the performance of the business that much better. The orientation of the innovation of an offender entrepreneurship can lead to an increase in the performance of the business also delivered by Covin and Slevin (1991).

\section{Market Orientation}

Narver and Slater (1990) define market orientation to be the most effective organizational culture for creating important behaviors in creating superior buyer value and performance. Furthermore (Narver and Slater, 1990) confirmed that market orientation includes (1) customer orientation, (2) competitor orientation, and (3) coordination between functions. Customer orientation is the company's ability to meet the needs of its customers and fully satisfy its customers now and in the future. Orientation competitors is the ability of the company to be able to know the strengths and weaknesses of competitors, as well as the strategies carried by competitors both now and in the future (Day and Wensley, 1988; Aaker, 1989; Porter and Schwab, 2008).

$$
\text { Jaworski and Kohli }
$$
emphasize on profitability which means that anything else is done by the seller to satisfy the customer should go back to the purpose of the main profitability. This means that companies are not allowed to build good relationships with customers by satisfying their needs, but at the expense of profit. Because of that, what else is done by the seller, they must remain within the framework of the purpose of the end of that advantage. Many experts in the field of marketing conclude that the main target is market orientation profitability or economic 
welfare and they find that profitability is a consequence of market orientation (Jaworski and Kohli, 1993). From the description in the above, can be concluded that the orientation on customers and orientation on competitors include all the information that relates to the needs of customers and the position of the company in the competition should be disseminated to all departments or units that exist within the organization. It is aimed that all departments or units that exist within an organization can identify and carry out follow-up. Coordination between functions should be based on customer information and competitor positions. Then, all of the functions or parts in the company making efforts that together to create value superior both to the business and customers. Finally, the company must focus on the goal-term long and principal to achieve profitability are high (Zainul, Astuti, Arifin, \& Nayati Utami, 2016).

\section{Entrepreneurial Commitment}

Commitment is a business that emerged from a businessman (Iturrioz, Aragon, and Narvaiza, 2014). Commitment can be formed through several experiences and one's educational support (Ciasullo \& Troisi, 2013). So if you do not have experience in a business, the entrepreneur 's commitment to entrepreneurship will also be shaken. Commitment also can arise because of their support of the market (Abosag \& Lee, 2013), where demand market that focus on a goods or services, sometimes led the employers to commitment to do its business.

Commitment is related to the attitude, behavior and sense of the entrepreneur to have a strong business in achieving company goals (Muda \& Rahman, 2016). It is has a meaning that the commitment of the entrepreneur is able to deliver entrepreneurs towards the performance of its best through the destination organization. This commitment relates to the behavior of the entrepreneur to the organization or business he does.
Commitment in the business industry is closely related to business consistency (Hayton, 2003). This consistency is closely related to the loyalty of entrepreneurs in running their business without changing the type of business. So it is consistent in running its business. In connection with the behavior of employers, commitment always talk related to three things namely affective, continuance and normative (Safari, Salehzadeh, Panahi, \& Abolghasemian, 2018). At least through the commitment of the entrepreneur, in the end it is able to influence business performance.

In industrial services in general, the commitment of employers used the excuse to increase profits (Abosag \& Lee, 2013), both intangibel or tangible. In addition, it is said that commitment is the basis of trust from entrepreneurs (Degli Antoni \& Grimalda, 2016). So that in improving the performance of the company not only from trust, it also requires the commitment of entrepreneurs. In how many cases of commitment so basic to establish a relationship, such as the relationship of business (Lombart \& Louis, 2014). Because with commitment, it is known business continuity between entrepreneurs or with their consumers. Due to the commitment of talk terkaitan closeness of the relationship of each other (Alam, 2016). With regard to developing good relationships for business and with consumers, entrepreneurs actually need to focus on several stages, namely awareness, exploration, expansion, commitment and dissolution (Robert Dwyer, 1987). Commitment poorer become one of the stages is important in establishing a relationship. So it is very important to be owned by entrepreneurs, including small entrepreneurs, in running a business through the commitment of entrepreneurs. The commitment in question is to focus on the business he is engaged in, as well as focus on the strategy he is carrying out. With the purpose of ending the performance of the business and the sustainability of its business. Need to note that the commitment can be rated by several factors, namely the 
commitment affective, commitment to continuous and commitment normative (Murty \& Hudiwinarsih, 2012)

\section{Business Performance}

According Moeherino (2012:95) performance is a measure of quantitative and qualitative that describes the level of achievement of an objective or objectives that have been set by the organization. Gibson et al. (2012) say that the performance of a series of activities management which gives an idea the extent to which the results were already achieved in the running duties and responsibilities it's in the form of accountability of public good in the form of success or shortcomings that occur. Achievement of the results of a series of activities which meant covering the standard result of work, targets or goals or criteria that have been determined since the early commencement of business. Man et al. (2002) stated that performance is the most important indicator to see success and this is proven both in real and in theory. With other words, the performance of the organization is the answer of a successful or whether the purpose of the organization that has been set. Definition of performance or the performance is the result of work that can be achieved by a person or group of people in a company in accordance with the authority and responsibility in charge of each in efforts to achieving the objectives the company is legal, does not violate the law and not contrary to morals and ethics (Riva et al, 2011).

According to Lumpkin and Dess (1996) the performance of the business can be said as a form that is commonly used to measure the impact of an orientation strategy of the company. The decline in business performance is certainly a problem and a challenge for the orientation of business strategies to be able to continue to maintain performance. Performance of business small and medium-sized is the effect of the ease in doing business, maker of policy and relevance of other stakeholders for the airport sector enterprises of small and medium-sized (Gaskill, 1993).

\section{MATERIALS \& METHODS \\ CONCEPTUAL FRAMEWORK}

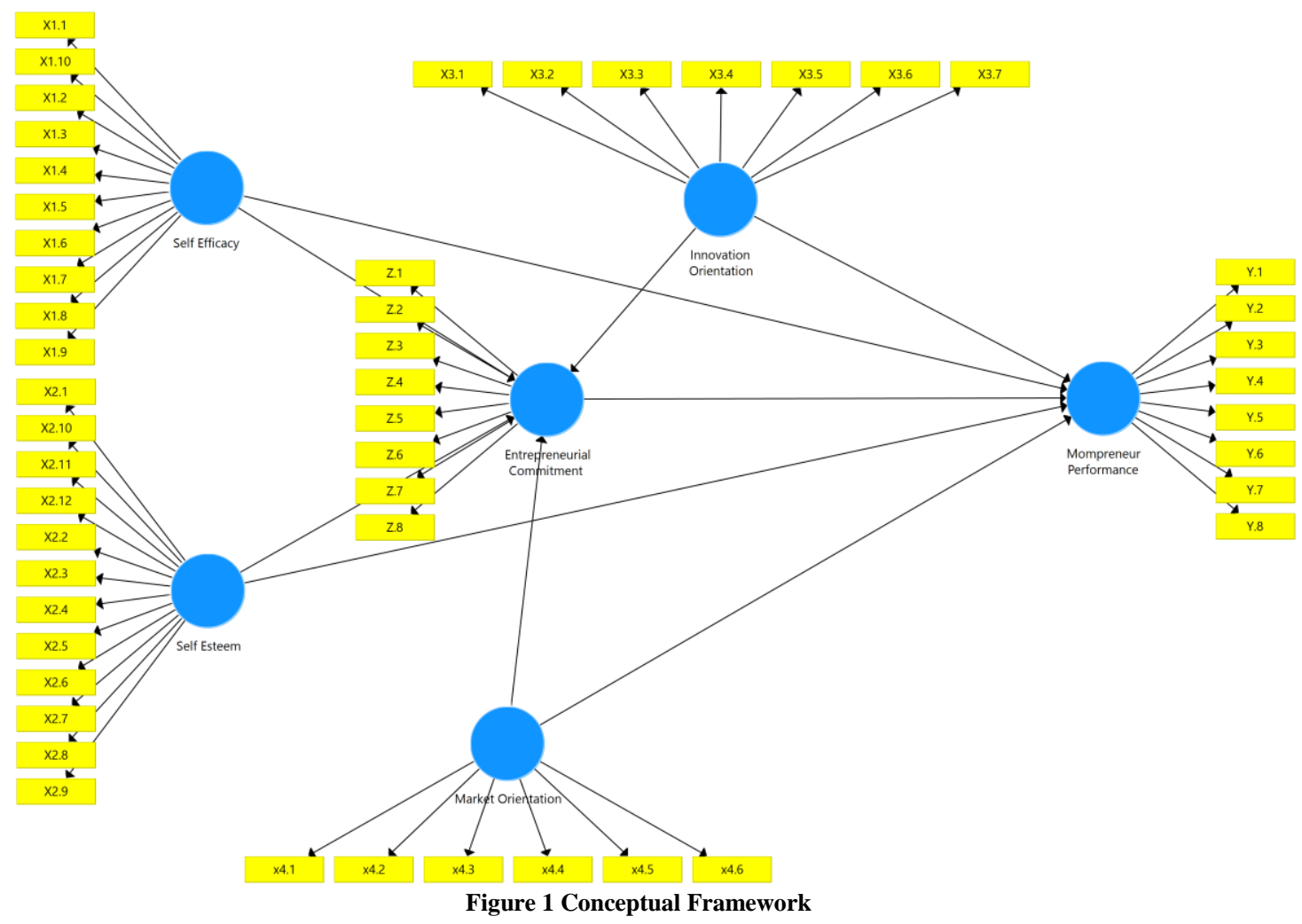




\section{RESEARCH METHODS}

Research this is the kind of research associative, which according to Sugiyono (2012), the study associative are studies that look at the relationship of variables or more. The population in the study this is mompreneur that exist in the city of Medan that number is not known. Because the number of samples was not known then used taking samples with a formula of theory Malhotra (2010) in which the number of items the question multiplied by at least 4 or 5. As for the question in the study is as much as 51 questions. By because the number of samples in research this is $51 \times 5$ $=255$ respondents. Mechanical taking samples using the technique of accidental sampling, where samples sought by random to determine the criteria mompreneur in Medan who have business at least 1 year. Metoden analysis of the data in the study is the method descriptive and analytical path by using smartPLS.

\section{RESEARCH RESULTS AND DISCUSSION}

\section{Respondent's Descriptive}

It is known that the respondents in the study are entirely manifold sex women who are at the age $>27$ years, where the average job is the mother house of stairs. Respondents in the study have already had a business $>1$ year with the kind of effort that is diverse as cosmetics, fashion, equipment home household and food

\section{Data Analysis Results}

Table 1: Test Results Effect of Direct and Non- Direct

\begin{tabular}{|l|l|}
\hline Direct Effect & P Values \\
\hline Self Efficacy -> Mompreneur Performance & $\mathbf{0 . 0 2 4}$ \\
\hline Self Efficacy -> Commitment to entrepreneurship & $\mathbf{0 . 0 4 6}$ \\
\hline Self Esteem -> Mompreneur Performance & $\mathbf{0 . 0 3 7}$ \\
\hline Self Esteem -> Commitment to entrepreneurship & $\mathbf{0 . 0 0 5}$ \\
\hline Innovation Orientation -> Mompreneur Performance & $\mathbf{0 . 0 2 3}$ \\
\hline Innovation Orientation -> Commitment to entrepreneurship & $\mathbf{0 . 0 0 0}$ \\
\hline Market Orientation -> Mompreneur Performance & $\mathbf{0 . 0 0 9}$ \\
\hline Market Orientation -> Commitment to entrepreneurship & $\mathbf{0 . 0 0 0}$ \\
\hline Commitment to entrepreneurship -> Mompreneur Performance & $\mathbf{0 . 0 0 1}$ \\
\hline Indirect Effect & $\mathbf{0 . 0 0 4}$ \\
\hline Innovation Orientation -> Commitment to entrepreneurship -> Mompreneur Performance & $\mathbf{0 . 0 3 1}$ \\
\hline Market Orientation -> Commitment to entrepreneurship -> Mompreneur Performance & $\mathbf{0 . 0 4 9}$ \\
\hline Self Efficacy -> Commitment to entrepreneurship -> Mompreneur Performance & $\mathbf{0 . 0 3 9}$ \\
\hline Self Esteem -> Commitment to entrepreneurship -> Mompreneur Performance & \\
\hline
\end{tabular}

\section{DISCUSSION}

Self-efficacy, self-esteem affects on the mompreneur performance and can be mediated by a commitment to entrepreneurship

Based on the results of the research, seen the influence of self efficacy and selfesteem of the performance of the business through a commitment to Air entrepreneurial thing is known through Table 1, which shows the influence that significant. Self efficacy is reflected by training, support from husband and family, desire for achievement and motivation for entrepreneurship. The desire of achievement has the value most substantial in reflecting self efficacy, case is explained that the desire of achievement or the need of achievement is a trait typical mompreneur, where mompreneur have need to compete and provide the best really describe personal than a mompreneur. The high desire to excel makes mompreneur strive hard to balance between its role into the mother house of stairs and as entrepreneurs. In addition to the desire of achievement, training becomes one of the indicators that reflect the factors of individuals from a mompreneur. Training in order to increase capacity and capability as an entrepreneur is a must for a mompreneur. The entrepreneurial behavior of mompreneurs is also influenced by self- 
esteem where the attitude of flexibility is the attitude that most reflects the entrepreneurial behavior of mompreneurs. Flexibility is becoming a key success mompreneur (Breen, 2014). The more flexible a mompreneur will be, the easier it will be to achieve the goals and targets of the business being managed. This flexible attitude is also closely related to the condition of the mompreneur who takes into account the opportunity cost when choosing to become an entrepreneur. There are costs to be incurred and time to be sacrificed when a mompreneur chooses to become an entrepreneur. For this reason, family support has a major influence in reflecting on selfefficacy. Support families that can be given not have to be a permit in writing that is formal, but it could be an agreement in writing or not writing between mompreneur with couples and families associated with the division of tasks in order to maximize the performance of the business. Support family is not directly going to affect the level of trust yourself mompreneur. Believe in yourself is one of the attitudes that reflect the behavior of entrepreneurs mompreneur, regard this shows belief themselves into characteristic typical and excellence of mompreneur. With high self- confidence, mompreneurs are able to carry out their dual roles without worries. Self esteem shown to affect motivation ber of entrepreneurs, especially with the growing development of e- commerce, Costin (2012) demonstrate the development of technology, information and communication (ICT) will increase also the number of mompreneur. The growing share of e-commerce market shows the share market more comprehensive and provide opportunities are great for mompreneur to expand the area of marketing. The area of marketing and income is an indicator in this study that can reflect the business performance of mompreneurs.

Market orientation, innovation orientation effect on the performance of mompreneur and can be mediated by a commitment to entrepreneurship
Based on Table 3 note that the orientation of the market and the orientation of the innovation has the effect that significant. So it can be concluded that that commitment bewirausaha of mompreneur will continue to rise if mompreneur oriented on the market and innovation, ka rena terms of this at the end will be able to improve the performance of mompreneur. In market orientation and innovation, there are several supporting factors, namely aspirations, goals and expectations. Factor is depicted on the willingness of employers in men entukan orientation which is owned by the business, in order to maximize efforts were made mompreneur in accordance with the commitment of her. Proceed with finesse mompreneur in meneta $\mathrm{p}$ kan purpose of business. Because it is not uncommon for mompreneurs to be confused with their business goals. The results of this study are in line with previous research from Gundry $\&$ Welsch (2001). But as if viewed over the visible relationship of the orientation of the market and the orientation of the innovation with the performance mompreneur not for the commitment to entrepreneurship, so it can be said that need their commitment to the high of mompreneur so it can improve its performance. Although the two have a good relationship

\section{CONCLUSION AND SUGGESTION} Conclusion

1. Directly self-efficacy, self-esteem, innovation orientation, market orientation affects positively and significantly to the mompreneur performance and commitment to entrepreneurship

2. Indirectly self-efficacy, self-esteem, innovation orientation, market orientation affects positively and significantly to the mompreneur performance through the commitment to entrepreneurship

\section{Suggestion}

Based on the discussion, the suggestion from the researcher is that good 
decisions are needed for mompreneurs in carrying out buying and selling activities, especially during the covid-19 pandemic like this. Then selecting decision alternatives are things important to resolve the problems that face to be able to optimize the purpose .Every mompreneur required to think critically and be sensitive there is a situation that is facing in order to maintain the stability of the business that it has. Be sensitive to opportunities and challenges in particular. Because a pandemic when it not only comes as a challenge to some sectors, but brings an opportunity for people who can see it. Not all people may know would chance it. By because it is, if mompreneur aware of the pandemic is a chance it will be able to bring its business to continue to thrive during a pandemic.

Also required the support of the government in order to attempt mompreneur also be more survive in the future. Given the pandemic is still kept there by because the government was also able to focus on business that is owned mompreneur to be more evolved, namely by providing a place and also training that could add to the competence mompreneur.

\section{ACKNOWLEDGEMENTS}

Research Institute in Universitas Sumatera Utara In Accordance With the Talenta Impementation Contract Number of the Universitas Sumatera Utara Fiscal Year 2021 Number: 6789/UN5.1.R/PPM/2021, 16 June 2021

\section{Conflict of Interest: None}

\section{Source of Funding: None}

\section{REFERENCES}

1. Alma B. 2010. Kewirausahaan Edisi Revisi. Bandung: Alfabeta

2. Casteleijn O. R. 2014. Comparing SenseMaking of Identities of Momprenuers in Malta and Finland. [Thesis]. Departement of Management and International Business Aalto University School Business.
3. Costin Y. 2012. ICT as an Enabler for Small Firm Growth; The Case of the Mompreneur [Internet]. hlm 1-3 [diunduh 20162 November]; Ireland (IE): University of Limerick.

4. Delmar F. 1996. Entrepreneurial Behaviour and Business Performance. [Dissertation]. Stockholm: Ekonomiska Forknings Institute.

5. Demirdag, Seyithan. (2015). Assessing Teacher Self Efficacy And Job Satisfaction : Middle School Teachers. Journal Of Educational and Instructual Studies In The World, Vol.5 (3/05). 3543.

6. Dharmmeta, Basu Swastha. 2018. Manajemen Pemasaran, Yogyakarta: BPFE

7. Duberly J.\& Carrigan M. 2012. The Career Identities of Mumpreneurs; Womens's experience of combining entreprise and motherhood. International Small Business Journal 31(6); 629-651

8. Ekinsmyth C. 2011. Challenging the Boundaries of Entrpreneurship. The Spatial and Practices of the UK Mompreneurs. Geoforum 42(1); 102-114.

9. Fauziyah D. 2015. Pengaruh karakteristik peternak melalui kompetensi peternak terhadap kinerja usaha ternak sapi potong di Kabupaten Bandung. [Tesis]. Bogor: Institut Pertanian Bogor

10. Gunaputri, Ga. Wulandari, Kusumaning, Ayu, \& Suana Iwayan. (2016). Pengaruh Self Efficacy, Locus Of Control Dan Goal Commitment Terhadap Kepuasan Kerja Karyawan Warung Mina Peguyangan Denpasar. E-Jurnal Manajemen Unud, Vol.5 (8), 5237-5263

11. Hasanah,Fahmin Sulus, 2017. Pengaruh orintasi pasar dan inovasi prodak dalam pemasaran.

12. Hendratni, T. W., \& Ermalina, E. (2018). Womenpreneur, Peranan Dan Kendalanya Dalam Kegiatan Dunia Usaha. Liquidity, 2(2).

13. Himam F, Saputri R K. 2015. Mindset Wanita Pengusaha Sukses. Jurnal Priskologi Volume 42 No. 2 Agustus 2015; 157-172.

14. Huet K R, Vial V, d'Andria A. 2013. Mumpreneurship: An New Concept for an 
Old Phenomenon? International Journal of Entrepreneurship and Small Business. DOI 10.1504/ IJESB.2013.054966.

15. Hughes K.D .2006. Exploratory Motivation And Success Among Canadian Womenentrepreneurship

16. Ilmer J. 2016. Why are 10 Million Moms Missing from The Workplace. [diuduh pada 201626 May]. Tersedia pada https://www.entrpreneur.com/article/2745 68.

17. Jean M dan Forbes C.S. 2011. Mompreneurs: An Exploration of Their Entrepreneurial Reality [Internet]. Journal of Business Diversity vol. 12(2) 201. Montreal, Canada (CA).

18. Kineta, M., Eunike, E., \& dkk. (2020). Corona Asyik. Universitas Katolik Soegijapranata.

19. Korsgaard S. 2007. Mompreneurship as a Challenge to the Growth Ideology of Entrepreneurship, Kontur, Vol. 16, No. 1

20. Latan H, Ghozali I. 2015.Partial Least Square Konsep,Tehnik, dan Aplikasi Menggunakan Program Smart PLS 3.0. Semarang (ID): Penerbit Universitas Diponegoro.

21. Malhotra, N.K. 2010. Marketing Research an Applied Orientation (5th ed). New Jersey: Pearson Education.

22. Martauli E.D. 2016. Faktor-Faktor Yang Mempengaruhi Kinerja Usaha Wanita Wirausaha Kerupuk Udang Di Provinisi Jambi [Tesis]. Bogor: Institut Pertanian Bogor.

23. Moorhead, Gregory, dan Griffin, Ricky W. (2013). Perilaku Organisasi (Manajemen Sumber Daya Manusia Dan Organisasi). Jakarta : Salemba Empat.

24. Mursid. 2015. Manajemen pemasaran. Jakarta: PT Bumi Aksara.

25. Nurhayati P, Sarianti T, Daryanto HK, Muflikh YN.2011. Analisis Pengaruh Karakteristik Kewirausahaan Terhadap Kinerja Wirausaha Pada Unit Usaha Kecil Menengah (Agroindusri) Di Kabupaten Bogor. Prosiding Seminar Penelitian Unggulan Departemen Agribisnis 2011.

26. Nurkidam, Qadaruddin, M., Bakri, M., Saleh, M., \& Musyarif. (2020). Coronalogy: Varian Analisis dan
Kontruksi Opini. IAIN Parepare Nusantara Press.

27. Nursiah T. 2015. Perilaku Kewirausahaan pada usaha mikro kecil (UMK) tempe di Bogor Jawa Barat [Tesis]. Bogor: Institut Pertanian Bogor

28. Rian Salangka, Lucky Dotulong, "Pengaruh Self efficacy, Self esteem dan Lingkungan Kerja Terhadap Kepuasan Kerja Karyawan pada PT. Pln (persero) Wilayah Suluttenggo", Jurnal Vol. 3 No. 3 (Manado: Fakultas Ekonomi dan Bisnis, Universitas Sam Ratulangi, 2015), h. 3.

29. Salangka, Rian \& Lucky Dotulong. (2015). Pengaruh Self Efficacy, Self Esteem Dan Lingkungan Kerja Terhadap Kepuasan Kerja Karyawan Pada PT. PLN (Persero) Wilayah Suluttenggo. Jurnal Emba, Vol.3 (3), 562-572.

30. Sapariyah, Rina Ani. (2011). Pengaruh Self Esteem, Self Efficacy Dan Locus Of Control Terhadap Kinerja Karyawan Dalam Perspektif Balance Scorecard Pada Perum Pegadaian Boyolali. Solo : STIE AUB Surakarta.

31. Sari. 2016. Pengaruh Karakteristik Kewirausahaan Terhadap Kinerja UMKM Gula Aren Di Kabupaten Lombok Barat [Tesis]. Bogor: Institut Pertanian Bogor.

32. Sarwono J, Narimawati U. 2014.Membuat Skripsi, Tesis Dan Disertasi Dengan Partial Least Square SEM (PLS-SEM). Yogyakarta(ID): Penerbit Andi

33. Sofiyah, F. R., \& Dilham, A. The Impact Of Internet Marketing On Success Of Women Micro, Small And Medium Enterprises And Innovation As Intervening Variable Case Study: Business Women In Medan City.

34. Sofiyah, F. R., \& Lubis, Y. M. (2018). Business management and entrepreneurship for the santri at pesantren ar-raudhatul hasanah medan. Abdimas talenta: Jurnal Pengabdian Kepada Masyarakat, 3(2), 159-164.

35. Sofiyah, F. R., \& Yulinda, M. (2018, January). The Influence Of Social Media On Buying Decisions On Women Small And Medium Enterprises (MSMEs) In North Sumatera. In 1st Economics and Business International Conference 2017 
Aisyah et.al. Determinants of mompreneur performance in the pandemic era (case study of Medan city mompreneurs).

(EBIC 2017) (pp. 515-520). Atlantis Press.

36. Sumantri B. 2013. Pengaruh jiwa kewirausahaan terhadap kinerja usaha wirausaha wanita pada industri pangan rumahan Di Bogor [Tesis]. Bogor: Institut Pertanian Bogor

37. Tambun T. 2012. Wanita Pengusaha UMKM Di Indonesia: Motivasi Dan Kendala. Jakarta (ID): Lembaga Penelitian Fakultas Ekonomi Universitas Trisakti.

38. Tjiptono, Fandy.2012. Pemasaran Strategik, Andi Offset, Yogyakarta.
39. Utaminingsih, Adijati. 2016. Pengaruh Orientasi Pasar, Inovasi, Dan Kreativitas Strategi Pemasaran Terhadap Kinerja Pemasaran Pada UKM Kerajinan Rotan Di Desa Teluk Wetan Welahan Jepara, Jurnal No. 2, Juli, Vol. 31.

How to cite this article: Aisyah, Hutagalung AQ, Sofiyah FR. Determinants of mompreneur performance in the pandemic era (case study of Medan city mompreneurs). International Journal of Research and Review. 2021; 8(9): 278-288. DOI: https://doi. org/10.52403/ijrr.20210938 